\title{
Implementasi Program Bimbingan Mengaji dalam upaya Meningkatkan Kemampuan Membaca AL-Qur'an Mahasiswa Universitas Pamulang Tangerang Selatan
}

\author{
Mustaqim', Moh. Jazuli² \\ ${ }^{1}$ Institut PTIQ Jakarta, Indonesia \\ 2 Universitas Pamulang, Indonesia \\ E-mail: elearning.mustaqim@gmail.com, dosen01680@unpam.ac.id
}

\begin{abstract}
Article Info
Article History

Received: 2021-05-12

Revised: 2021-07-22

Published: 2021-08-15

Keywords:

Implementation;

Recitation Guidance;

Students' Ability;

Reading;

AL-Qur'an.

Abstract

This study aims to determine the implementation of the Qur'an guidance program at Pamulang University, South Tangerang, which includes policies, management, and the efforts made by the campus in improving the ability to read Al-Qur'an of Unpam students. This research uses a qualitative approach with a descriptive analysis method. The technique of selecting informants is using purposive sampling technique, Pamulang University's recitation program is a program to develop Islamic Education courses with a grassroots model which is mandatory for early semester students which aims to eradicate Al-Quran illiteracy or to improve students' reading ability of the $\mathrm{Al}$ Qur'an to a higher level. This program is supported by the rector and the Directorate General of Islamic Education of the Ministry of Religion, The result shows that the teaching method for reading Al-Qur'an in Unpam which uses the basic tahsin I, II, III, and advanced methods, seems not comprehensive enough because it only touches the theoretical area. This can be seen in the practice of Qur'an teaching guidance, there are difficulties in measuring the success of students which have weak abilities in reaching predetermined levels. Meanwhile, the success of the qiraa'ah mujawwad method for potential students was mostly successful because it was supported by student backgrounds and the existence of hours of intensive training conducted at the home of the lecturer.
\end{abstract}

\begin{tabular}{l}
\hline Artikel Info \\
\hline Sejarah Artikel \\
Diterima: 2021-05-12 \\
Direvisi: 2021-07-22 \\
Dipublikasi: 2021-08-15
\end{tabular}

Kata kunci: Implementasi; Bimbingan Mengaji; Kemampuan; Membaca; AL-Qur'an.

Abstrak
Penelitian ini bertujuan untuk menganalisa peningkatan kemampuan mengaji
mahasiswa melalui program Kampus Unpam Mengaji (KUM) di Universitas Pamulang
Tangerang Selatan meliputi pengelolaan, metode dan upaya yang dilakukan kampus
dalam meningkatkan kemampuan mengaji mahasiswa Unpam. Penelitian ini
menggunakan pendekatan kualitatif dengan metode deskriptif analisis. Teknik
pemilihan informan menggunakan teknik purposive sampling, Program mengaji
Universitas Pamulang merupakan sebuah program pengembangan kurikulum mata
kuliah Pendidikan Agama Islam dengan model grassroot bersifat wajib bagi mahasiswa
semester awal yang bertujuan untuk memberantas buta huruf Al-Qur'an atau
meningkatkan kemampuan membaca Al-Qur'an mahasiswa kepada tingkat yang lebih
tinggi. Program ini mendapatkan dukungan oleh rektor dan Ditjen Pendidikan Islam
Kementerian Agama, Hasil menunjukkan bahwa metode bimbingan membaca Al-
Qur'an di Unpam yang menggunakan metode tahsin dasar I, II, III, dan lanjutan
nampaknya belum bisa meningkatkan kemampuan mahasiswa secara signifikan
terutama pada level dasar karena pada praktiknya penggunaan metode ini masih
belum fokus dan kurang komprehensif. Hal ini terlihat dari belum adanya kurikulum
dan sistem evaluasi yang baku sehingga masing-masing dosen berbeda dalam
membimbing dan melakukan ujian tingkatan-tingkatan yang telah ditentukan.
Sedangkan bagi mahasiswa potensial yang mempelajari qiraa'ah mujawwad, sebagian
besar berhasil meningkat karena dipengaruhi oleh latar belakang pendidikannya dan
juga didukung adanya jam belajar tambahan yang dilakukan di rumah dosen
pembimbing.

\section{PENDAHULUAN}

Universitas Pamulang (Unpam) sebagai salah satu lembaga pendidikan tinggi umum memiliki sebuah kebijakan yang inovatif. Berdasarkan visi dan misi Unpam yang salah satunya yaitu menyelenggarakan pendidikan yang berbasis humanis dan religius, Unpam memiliki sebuah program yang merupakan pengayaan kurikulum Pendidikan Agama Islam, yaitu program mengaji Al-Qur'an. Menurut koordinator program 
mengaji Universitas Pamulang ini, Salah satu tujuan diadakan program ini tidak lain untuk menanggulangi masalah buta huruf Al-Qur'an.

Dengan mengeluarkan kebijakan program mengaji, Unpam merupakan salah satu kampus yang mempunyai perhatian terhadap kapabilitas mengaji Al-Qur'an mahasiswa-mahasiswinya. Program ini perlu mendapat dukungan dan apresiasi baik dari pemerintah maupun dari masyarakat karena fenomena semacam ini sangat jarang ditemukan apalagi Unpam merupakan sebuah kampus Umum. Tetapi di sisi lain, penulis juga memiliki analisa lain bahwa dengan diwajibkannya program ini berpotensi akan menemui kendala-kendala dalam pelaksanaannya dengan beberapa alasan. Pertama, program ini tidak memiliki landasan yang cukup kuat. Seperti yang peneliti ketahui, berdasarkan peraturan dari Kemenristek tentang kurikulum perguruan tinggi umum (PTU), materi kurikulum yang diatur hanyalah mata kuliah agama Islam, tidak membahas secara rinci tentang program mengaji. Meskipun memang di dalam rencana pembelajaran semester (RPS) mata kuliah agama tersebut mengkaji tentang AlQur'an.

Kedua, sebuah program wajib dengan jumlah mahasiswa yang banyak sangatlah sulit jika hanya dikelola oleh guru mata kuliah PAI. Pengamatan penulis senada dengan penjelasan Muhaimin (2010) bahwa untuk mengelaborasi Pendidikan Agama Islam di perguruan tinggi umum dibutuhkan adanya keterkaitan antara beberapa unsur seperti: penyesuaian dari mahasiswa dari berbagai latarbelakang, program kurikulum, tenaga pendidikan, sarana prasarana, biaya, manajemen, proses KBM, serta lingkungan yang baik akan dapat menghasilkan keluaran atau hasil yang sesuai harapan dari Pendidikan Agama Islam. Oleh karena itu diperlukan sebuah kajian untuk menelaah implementasi program keagamaan di perguruan tinggi umum.

Ketiga, program mengaji di Unpam tidak memiliki SKS alias nol SKS dan tidak menjadi syarat kelulusan mahasiswa. Jika sebuah program tidak memiliki SKS dan tidak juga menjadi mata kuliah syarat kelulusan bagi mahasiswanya maka kemungkinan besar akan timbul permasalahan selanjutnya. Keempat, mudah ditinggalkan oleh mahasiswanya. Hal tersebut sudah menjadi rahasia umum, bahwa desain pendidikan tinggi tidak seperti pada pendidikan dasar dan menengah, yang memiliki sistem, didukung juga karakter mahasiswa yang cenderung bebas dan tidak terikat semacam tata tertib seperti yang ada pada sekolah dasar dan menengah.

Akan tetapi, di luar dari asumsi-asumsi peneliti tentang program mengaji di Unpam, secara umum peneliti sangatlah mendukung adanya program mengaji yang ada di kampus Unpam ini sebagai sebuah inovasi pemberantasan buta aksara Al-Qur'an pada jenjang pendidikan perguruan tinggi umum. Menyadari akan pentingnya program bimbingan mengaji sebagai usaha mencari solusi kelemahan dalam mengaji Al-Qur'an, peneliti tertarik untuk mengangkat fenomena ini menjadi sebuah kajian "Implementasi program bimbingan mengaji dalam upaya meningkatkan kemampuan membaca Al-Qur'an mahasiswa Universitas Pamulang Tangerang Selatan".

\section{METODE PENELITIAN}

Jenis Penelitian yang digunakan dalam penelitian ini adalah deskriptive (analisis) kualitatif, dengan Sample penelitian ini dipilih secara purposive sampling, Peneliti menentukan sampel sesuai kriteria tertentu agar terfokus pada tujuan penelitian yang telah ditetapkan, Teknik analisis data yang digunakan dalam penelitian ini adalah teknik analisis data kualitatif deskriptif. Miles dan Huberman (Sugiyono, 2017: 337) mengemukakan bahwa aktivitas dalam analisis data kualitatif dilakukan secara interaktif dan berlangsung secara terus menerus sampai tuntas, sehingga datanya sudah jenuh.

\section{HASIL DAN PEMBAHASAN}

a) Kebijakan Mata Kuliah Pendidikan Agama Islam di Universitas Pamulang

Mendapatkan pengajaran tentang agama Islam dengan baik yang sejajar dengan kelas perkuliahan lainnya pada perguruan tinggi umum merupakan hak semua mahasiswa muslim. Hal ini sudah menjadi kewajiban bagi kampus untuk memasukkan pendidikan agama, salah satunya Islam dalam kurikulum pendidikannya. Pernyataan ini sesuai dengan amanat Undang-undang Republik Indonesia No. 20 Tahun 2003 tentang Sistern Pendidikan Nasional dalam BAB V mengenai Peserta Didik pada Pasal 12 Ayat 1 yang diamanatkan bahwa setiap peserta didik pada setiap satuan pendidikan berhak memperoleh pendidikan agama sesuai dengan agama yang dianutnya dan diajarkan oleh pendidik yang seagama. Juga mengacu Pasal 12 Ayat 2 pada Bab X tentang Kurikulum yang menyatakan 
bahwa pendidikan tinggi wajib memuat kurikulum pendidikan agama, pendidikan kewarganegaraan, dan bahasa.

Mata kuliah Pendidikan Agama Islam di Universitas Pamulang dilihat dari segi fungsinya merupakan topik yang sangat penting untuk memberikan masukan bagi ideide yang dapat mengubah kepribadian dan karakter mahasiswa yang berhubungan dengan religiusitas. Dengan demikian, diharapkan tujuan utama mata kuliah agama Islam di perguruan tinggi umum tidak hanya terpusat pada proses pendidikan bagi mahasiswa yang sejak awal belum memahami agama menjadi lebih paham, atau dari mereka yang belum menerapkan prinsip-prinsip agama, serta dari seseorang yang belum taat menjadi lebih taat dalam menjalankan syariatNya. Akan tetapi lebih jauh lagi, Pendidikan Agama Islam adalah internalisasi nilai-nilai keislaman secara penuh, terutama dalam kehidupan mahasiswa berdasarkan pemikiran dan pengamalan.

Dalam penyelenggaraan Pendidikan Agama Islam di Universitas Pamulang, sesuai dengan kurikulum pendidikan agama yang ditetapkan oleh Kementerian Riset, Teknologi, dan Pendidikan Tinggi, pendidikan agama dalam hal ini Islam hanya menerima 2 SKS. Dalam pengimplementasian Pendidikan Agama Islam di Perguruan Tinggi Umum, terutama pada Perguruan Tinggi Umum yang berstatus swasta terdapat inovasi-inovasi baru berkaitan dengan kurikulum PAI. Salah satu contoh yaitu implementasi mata kuliah PAI di Universitas Pamulang (Unpam). Sesuai dengan kurikulum Pendidikan Agama yang telah di buat oleh Kemenristekdikti, bahwa pendidikan agama, dalam hal ini Agama Islam, hanya mendapatkan alokasi sebanyak 2 SKS saja. Di dalam rencana pembelajaran semester (RPS) nya, mata kuliah PAI berisi tentang diskusi akidah, syari'ah, ekonomi Islam, dan Qur'an Hadits. Namun, dalam praktiknya para pengajar mata kuliah PAI di kampus Unpam berinovasi untuk membuat program bimbingan mengaji yang bertujuan memfasilitasi mahasiswanya untuk belajar AlQur'an sesuai dengan tingkat kebutuhan masing-masing.

Dapat disimpulkan bahwa program bimbingan mengaji di kampus Unpam tidak secara implisit ada dalam kurikulum atau Rencana Pembelajaran Semester (RPS), melainkan secara eksplisit sebagai sub inti pembelajaran tema tentang Al-Qur'an, Nana Syaodih Sukmadinata (2006) menjelaskan, model pengembangan kurikulum harus disinkronisasi dengan sistem pendidikan dan sistem manajemen pendidikan yang dianut, serta model pendidikan yang akan digunakan. Lebih lanjut, penggunaan model pengembangan kurikulum dalam sistem dan manajemen pendidikan yang terpusat berbeda dengan yang terpusat, dan model pengembangan dalam kurikulum yang merupakan mata pelajaran akademik berbeda dengan kurikulum humanistik, teknologi dan rekonstruksi sosial. Setidaknya ada beberapa macam model pengembangan menurut Sukmadinata (2006) yang antara lain:

1. Model administrasi, merupakan model tertua dan paling terkenal. Istilah lain untuk model ini adalah top-down atau staf lini, karena inisiatif dan ide pengembangan berasal dari penyelenggara pendidikan dan menggunakan prosedur administratif. Yakni, tim khusus direktur pengembangan kurikulum yang terdiri dari para pejabat di antaranya, pakar pendidikan, pakar kurikulum, pakar disiplin ilmu, dan tokoh dari dunia kerja dan perusahaan.

2. Model akar rumput (grass roots), merupakan kebalikan dari model administrasi, Inisiatif-inisiatif berasal dari bawah yakni pengajar-pengajar atau sekolah.

3. Model demonstrasi, model ini pada dasarnya adalah akar rumput dan berasal pengajar atau sekolah.

4. Model Taba's inverted, Ada beberapa tahapan dalam mengembangkan kurikulum versi Taba: pertama, pelaksanaan unit eksperimen dengan pengajar, maksudnya dengan melakukan kajian menyeluruh tentang hubungan teori dan praktik.

Menurut Abdullah Idi (2007) paling tidak ada delapan tahapan pada aktivitas unit eksperimen, antara lain: diagnosis kebutuhan, perumusan tujuan-tujuan spesifik, pemilihan konten, pengorganisasian konten, pemilihan pengalaman belajar, pengorganisasian pengalaman belajar, evaluasi, dan pengamatan akan keteraturan dan keseimbangan, Implementasi kebijakan sebagaimana penjelasan Edwards III dalam Subarsono (2005), sangat dipengaruhi oleh empat hal, antara lain: sumberdaya, komunikasi disposisi, dan struktur birokrasi. Semua aspek dari masing- 
masing itu memiliki keterkaitan satu sama lain, antara lain adalah:

1. Communcation (komunikasi)

Penerapan kebijakan yang berhasil membutuhkan pedoman kebijakan untuk melihat apa yang harus dilakukan. Sasaran atau spesifikasi yang harus dimiliki pedoman harus dikomunikasikan diteruskan kepada kelompok sasaran sehingga dengan komunikasi yang baik perubahan bentuk dalam proses implementasi dapat dikurangi.

2. Resources (sumber daya)

Meskipun pedoman tersebut dikomunikasikan dengan jelas dan konsisten, namun jika sumber daya pelaksanaan pedoman tersebut masih kurang, maka implementasinya cenderung menjadi tidak efektif. Betuk sumber daya dapat berupa sumber daya manusia yaitu kemampuan melaksanakan kebijakan, dan sumber keuangan.

3. Dispotition (disposisi)

Disposisi adalah pandangan yang dimiliki oleh pelaksana kebijakan. Jika penegak kebijakan memiliki pandangan yang baik, mereka dapat menjalankan kebijakan dengan baik sesuai keinginan pembuat kebijakan. Jika penegak kebijakan mempunyai sikap atau pandangan yang berbeda dari pembuat kebijakan, maka penegakan kebijakan menjadi tidak efektif.

4. Bureaucratic Structure

Bureaucratic structure atau struktur organisasi berarti melaksanakan kebijakan yang berdampak baik kepada implementasi kebijakan. Di antara struktural yang utama dari sebuah lembaga yaitu adanya langkah-langkah atau biasa disebut SOP. SOP merupakan acuan para pelaksana kebijakan dalam berbicara dan bekerja.

Sedangkan indikator pelak-sanaan program yang efektif menurut Andang (2007) dapat dilihat dari segi input, proses dan outputnya. Jadi, kebijakan yang efektif mendeskripsikan keseluruhan siklus input, proses dan output yang berpedoman kepada hasil dari sebuah lembaga, program atau aktivitas yang umumnya menjelaskan seberapa besar tujuan baik dari kualitas maupun kuantitas, berhasil tidaknya suatu organisasi dalam mencapai tujuannya dan mencapai target-targetnya. Hal ini menunjukkan bahwa efektivitas kebijakan secara sederhana dapat dinilai dari hasil atau capaian tujuan.

b) Arti Penting Program Mengaji di Unpam

Kampus Unpam pada salah satu visi misinya mengharapkan bahwa mahasiswamahasiswi lulusannya memiliki karakter humanis religius, penyelenggaraan pendidikannya berdasar humanis dan religius, pelaksanakan penelitiannya juga berdasar humanis dan religius, serta pengabdian masyarakatnya juga berasaskan humanis dan religius. Hal ini menunjukkan bahwa Unpam memiliki perhatian kepada nilai-nilai humanis dan religius dari pelaksaan, penelitian, dan pengabdian kampusnya sehingga pada proses input perkuliahannya kampus tersebut memasukkan program-program yang berkaitan dengan mata kuliah agama salah satunya seperti program mengaji.

Jika mengacu kepada Kamus Besar Bahasa Indonesia (2021) menjelaskan bahwa kata religius memiliki arti bersifat keagamaan; yang bersangkut-paut dengan religi. Nilai religius merupakan konsep yang berkaitan dengan penghormatan besar yang diberikan anggota masyarakat terhadap berbagai persoalan besar dalam kehidupan beragama yang bersifat sakral sehingga dijadikan pedoman perilaku beragama anggota masyarakat yang bersangkutan. Arti religiusitas lebih luas (universal) dari pada agama, karena agama terbatas pada ajaran atau aturan, artinya merujuk pada agama tertentu (pendidikan). Untuk itu, dalam membahas nilai-nilai agama yang lebih spesifik pada ajaran agama tertentu juga digunakan acuan pada ajaran agama tertentu. Dalam hal ini kampus Unpam tidak hanya dikhususkan untuk calon mahasiswa yang beragama Islam, akan tetapi juga agama lain meskipun persentasinya hanya sedikit, Menurut Mangunwijaya (1982), ada beberapa macam nilai dalam konsep religus antara lain:

1. Nilai religius tentang hubungan manusai dengan Tuhannya.

2. Nilai religius tentang hubungan sesama manusia.

3. Nilai religius tentang hubungan manusia dengan alam atau lingkungan.

4. Nilai religius yang berkaitan dengan pendidikan keagamaan.

Dari beberapa uraian di atas dapat dikatakan bahwa religius merupakan suatu sikap kokoh dalam menjalankan ajaran agama 
juga merupakan sebuah cerminan diri atas kepatuhan dalam melaksanakan ajaran agama yang telah dianut oleh seseorang. Seperti yang telah diyakini oleh umat Islam, dan seperti apa yang telah di lakukan oleh para dosen Pendidikan Islam di Universitas Pamulang bahwa menurut mereka kegiatan membaca Al-Qur'an merupakan sebuah program pendukung untuk meningkatkan sikap religius karena aktivitas membaca Al-Qur'an juga termasuk ibadah yang utama dan sangat dianjurkan oleh agama Islam. Sebagaimana sabda Rasulullah Saw. bahwa sebaik-baiknya ibadah umat beliau adalah membaca AlQur'an. Dapat dikatakan bahwa program mengaji yang dilaksanakan di kampus ini merupakan sebuah usaha untuk merealisasikan visi misi kampus tentang sikap religius dengan memberikan program pengembangan kemampuan mengaji agama Islam, salah satunya yaitu dengan membaca Al-Qur'an.

c) Tujuan Program Bimbingan Mengaji di Unpam Sebuah program sudah seharusnya memiliki tujuan, apalagi sebuah program yang memiliki cakupan luas seperti universitas, pastinya sudah dipertimbangkan dan rumuskan dengan baik. Robert F. Mager yang dikutip Suharsimi Arikunto (2002) mengemukakan bahwa tujuan sebuah program pembelajaran adalah perilaku yang hendak dicapai atau yang dapat dikerjakan oleh mahasiswa pada kondisi dan tingkat kompetensi tertentu. Standar proses pada Permendiknas Nomor 41 Tahun 2007 menyatakan bahwa tujuan pembelajaran menggambarkan proses dan hasil belajar yang diharapkan dicapai oleh peserta didik sesuai dengan kompetensi dasar. Ini berarti kemampuan yang dirumuskan dalam tujuan pembelajaran mencakup kemampuan yang akan dicapai mahasiswa selama proses belajar dan hasil akhir belajar pada suatu kompetensi dasar.

Ketua Lembaga Kajian Keagamaan Universitas Pamulang menerangkan bahwa salah satu tujuan diadakan program ini tidak lain untuk menanggulangi masalah buta huruf Al-Qur'an. Sofyan Hadi menjelaskan bahwa

"Indikatornya kita buat bahwa diharapkan dengan program ini mahasiwa Unpam bisa mengaji, membaca, dan membebaskan buta huruf. Jadi karena kebanyakan mereka bukan dari latar belakang pesantren." (wawancara, 17 Oktober 2020).
Melihat penjelasan di atas, tampak bahwa tujuan dari pelaksanaan program mengaji AlQur'an di kampus ini adalah untuk dapat meningkatkan kemampuan mengaji mahasiswanya.

d) Metode Bimbingan Mengaji di Unpam

Metode bimbingan program mengaji di Universitas Pamulang pada dasarnya tidak mengacu secara spesifik kepada metode yang telah ada di Indonesia. Pada awal dimulainya program mengaji misalnya, program tersebut hanya berbentuk khataman. Mukhayyaroh menjelaskan bahwa:

"saya sudah mengawali mengawali kegiatan KUM dari sejak dari 2016, saya ada tahsin tilawah ketika tatap muka, atau ketika kajian, juga saya membentuk oneman khataman." (wawancara, 17 Oktober 2020).

Sebuah metode memiliki peranan penting dalam pembelajaran, Penggunaan metode yang tepat sangat mempengaruhi dalam proses belajar mengajar. Metode yang cocok diperlukan karena subjek program ini adalah para mahasiswa-mahasiswa, sehingga dianggap tidak membuat malu mereka jika mengikuti program bimbingan mengaji, terlebih bagi mahasiswa-mahasiswi yang memiliki kemampuan mengaji rendah. Seperti yang diungkapkan oleh Sudjana yang menjelaskan bahwa metode pembelajaran adalah cara yang digunakan guru untuk berinteraksi dengan siswa pada saat pembelajaran berlangsung. Seperti yang dijelaskan oleh Basyirudin (2002) bahwa metode adalah bagaimana cara atau teknik menyajikan bahan pelajaran terhadap siswa agar tercapai suatu tujuan yang ditetapkan secara efektif dan efesien. Dengan kata lain metode merupakan suatu cara yang dipergunakan untuk mencapai tujuan yang telah ditetapkan.

Program bimbingan mengaji di kampus Unpam yang diperuntukkan bagi mahasiswa juga perlu dilaksanakan dengan pendekatan yang berbeda dengan siswa TPQ yang pada umumnya adalah anak-anak. Proses bimbingan mengaji harus dilaksanakan dengan pendekatan yang tepat. Tidak jarang ditemui mahasiswa yang malu karena merasa kemampuan membaca Al-Qur'annya kurang. Misalkan menggunakan pendekatan humanistik yang memiliki konsep "memanusiakan orang". Nasution

(1999) 
menerangkan terciptanya situasi yang memberikan kesempatan kepada manusia untuk menjadi lebih manusiawi, meningkatkan harkat dan martabat manusia, merupakan landasan falsafah, landasan teori, landasan evaluasi dan landasan pengembangan ke depan. Pendekatan humanistik didasarkan pada apa yang terkadang disebut "psikologi humanistik", yang terkait erat dengan teori psikologi lapangan dan kepribadian terutama Maslow, pada tahun 2018, menurut Mukhlisin sebagai koordinator program mengaji, terutama materi membaca Al-Qur'an telah mengalami penyempurnaan, diadakan pembagian level mahasiswa berdasarkan kemampuan sebagai berikut:

Tabel 1. Materi bimbingan membaca Al-Qur'an

\begin{tabular}{cl}
\hline Level & \multicolumn{1}{c}{ Materi Bimbingan } \\
\hline Dasar I & $\begin{array}{l}\text { Pengenalan Huruf Hijaiyah, Makhorijul } \\
\text { huruf, Sifatul Huruf, Hukum Nun mati, } \\
\text { Mim Mati }\end{array}$ \\
\hline Dasar II & $\begin{array}{l}\text { Hukum nun mati, Hukum mim mati, } \\
\text { Qalqalah, Hukum al ta'rif, Lafdzul } \\
\text { jalalah, Hukum ra' }\end{array}$ \\
\hline Dasar III & $\begin{array}{l}\text { Idgham mutamatsilain, Idgham } \\
\text { mutajanisain, Idgham mutaqaribain, } \\
\text { dan Hukum-hukum mad. }\end{array}$ \\
\hline Lanjutan & Grorib, Fawatihus suwar. \\
\hline $\begin{array}{l}\text { Mahasiswa } \\
\text { potensial. }\end{array}$ & Qiraah Mujawwad: Naghom \\
\hline
\end{tabular}

Dalam pelaksanaan bimbingan, dosen PAI yang bertindak sekaligus sebagai pembimbing mengaji juga harus mengatur bagaimana agar proses belajar menjadi efisien karena jumlah mahasiswanya banyak dan masing-masing memiliki kemampuan yang berbeda. Upaya meningkatkan kemam-puan membaca AlQur'an, dengan membagi level tahsin mensyaratkan para pengajar untuk menguasai detail-detail materinya. Jika mahasiswa yang dilibatkan untuk membatu mengajar seorang dosen, berarti materi tersebut memang harus dikuasai sebelumnya.

f) Faktor Penghambat Metode Mengaji di Kampus Unpam

Dalam pengorganisian sebuah program belajar, sudah tentu ada hal yang menjadi tantangan dan hambatan. Sebuah hambatan harus didentifikasi untuk kemudian dicarikan cara baru untuk diimplementasikan di tahun- tahun mendatang. Ada beberapa kendala yang dihadapi dalam melaksanakan program mengaji Unpam antara lain penjelasan oleh ketua LKK, Sofyan Hadi, menyampaikan bahwa waktu bimbingan bersamaan dengan jadwal kuliah lain, terkadang waktu (bimbingan) yang kurang memadai karena rata-rata mahasiswa selain tugas belajar di kampus mereka juga bekerja (wawancara, 27 Oktober 2020). Hal senada juga disampaikan oleh koordinator KUM, Mukhlisin, mengatakan bahwa kurikukum mengaji belum dibakukan sehingga target tidak tercapai maksimal (wawancara, 22 Oktober 2020). Seorang mahasiswa, Ridho, juga mengatakan minat mahasiswa untuk mengikuti program mengaji masih kurang, tidak semua mahasiswa baru Unpam mengikuti program ini dengan baik, tergantung pribadi masingmasing (wawancara, 24 Oktober 2020). Temuan lain seperti diungkapkan seorang mahasiswi, Aliya, menyatakan bahwa belum ada evaluasi kepada mahasiswa baik secara tertulis maupun lisan (wawancara, 23 Oktober 2020).

\section{g) Efektivitas Program Mengaji di Kampus Unpam}

Setiap program belajar ataupun kurikulum sudah pasti memiliki kelebihan dan kekurangan. Untuk mengetahui kelebihan dan kekurangan, perlu adanya sebuah indikator keberhasilan diukur. Berdasarkan apa yang dikemukakan oleh Andang (2014) mengenai indikator pelaksanaan program yang efektif dapat dilihat dari input, proses, dan output. Beberapa indikator tersebut relevan digunakan dalam mengukur jalannya program mengaji di Universitas Pamulang antara lain sebagai berikut:

Tabel 2. Pengukuran implementasi program mengaji Unpam

\begin{tabular}{|l|l|}
\hline \multicolumn{1}{|c|}{$\begin{array}{c}\text { Indikator } \\
\text { pengukuran }\end{array}$} & \multicolumn{1}{|c|}{ Keterangan } \\
\hline $\begin{array}{l}\text { Input } \\
\text { 1) Memiliki } \\
\text { kebijakan }\end{array}$ & $\begin{array}{l}\text { Didukung SK Rektor dan SK } \\
\text { Pendis Kemenag. }\end{array}$ \\
2) $\begin{array}{l}\text { Memiliki } \\
\text { sasaran dan } \\
\text { tujuan. }\end{array}$ & $\begin{array}{l}\text { Sasaran program yaitu semua } \\
\text { mahasiswa baru. Sedangkan } \\
\text { Tujuan untuk meningkatkan } \\
\text { kemampuan } \\
\text { mahasiswa. }\end{array}$ \\
& $\begin{array}{l}\text { Dosen-dosen PAI Unpam rata- } \\
\text { rata adalah lulusan PTIQ, UIN, } \\
\text { dan Al-Azhar Mesir. }\end{array}$ \\
\hline $\begin{array}{l}\text { Memiliki } \\
\text { manumer daya }\end{array}$
\end{tabular}




\begin{tabular}{|c|c|}
\hline $\begin{array}{l}\text { ajar yang } \\
\text { kompeten. } \\
\text { 4) Fokus pada } \\
\text { tujuan }\end{array}$ & $\begin{array}{l}\text { Kurang fokus karena kurikulum } \\
\text { belum dibakukan }\end{array}$ \\
\hline $\begin{array}{l}\text { Proses } \\
\text { 1) Proses KBM } \\
\text { yang efektif }\end{array}$ & $\begin{array}{l}\text { Sudah tersedia jadwal, namun } \\
\text { terkadang waktu bersamaan } \\
\text { dengan mata kuliah lain. }\end{array}$ \\
\hline $\begin{array}{l}\text { 2) Pengelolaan } \\
\text { yang efektif }\end{array}$ & $\begin{array}{l}\text { Masih terdapat perbedaan } \\
\text { antar pembimbing tentang } \\
\text { pelaksanaan program mengaji. }\end{array}$ \\
\hline $\begin{array}{l}\text { 3) Lingkungan } \\
\text { mendukung }\end{array}$ & $\begin{array}{l}\text { Lingkungan mendukung, semua } \\
\text { Kaprodi mendukung. }\end{array}$ \\
\hline $\begin{array}{l}\text { 4) Partisipasi } \\
\text { yang tinggi }\end{array}$ & $\begin{array}{l}\text { Sebagian besar } \\
\text { mengikuti, tetapi ada yang } \\
\text { kurang berminat. }\end{array}$ \\
\hline $\begin{array}{l}\text { 5) Melakukan } \\
\text { evaluasi } \\
\text { berkala }\end{array}$ & $\begin{array}{l}\text { Sebagian pembimbing ada yang } \\
\text { melakukan evaluasi secara } \\
\text { tertulis, sebagian hanya melalui } \\
\text { lisan, sebagian belumm } \\
\text { melaksanakan evaluasi. }\end{array}$ \\
\hline $\begin{array}{l}\text { Output } \\
\text { Capaian/ prestasi } \\
\text { yang dihasilkan } \\
\text { oleh program } \\
\text { mengaji. }\end{array}$ & $\begin{array}{l}\text { Bagi mahasiswa potensial, } \\
\text { terdapat lomba MTQ antar } \\
\text { mahasiswa potensial. Persenta- } \\
\text { sinya sangat kecil. } \\
\text { Bagi mahasiswa yang berkema- } \\
\text { mpuan kurang, Peningkatan } \\
\text { kemampuannya tidak signifik- } \\
\text { an, yaitu peningkatan wawasan } \\
\text { tentang ilmu qiro'ah. Paling } \\
\text { tinggi meningkat terbatas pada } \\
\text { membaca surat-surat pendek } \\
\text { sesuai dengan kaidah tajwid. }\end{array}$ \\
\hline
\end{tabular}

Dapat dianalisis bahwa pelaksanaan program mengaji di Universitas Pamulang, jika dianalisis pada tahap input terlihat bahwa pelaksanaan program mengaji di Universitas Pamulang masih belum berjalan maksimal karena kurikulum program mengaji masih belum dibakukan, apalagi program kampus mengaji juga tidak memiliki modul khusus, sehingga terjadi perbedaan persepsi cara pelaksanaan dan pembimbingan masingmasing dosen. Padahal jika dilihat dari sumber daya pengajar, Universitas Pamulang memiliki dosen yang berkualifikasi dalam hal membaca al-Qur'an. Kedua, pada tahap proses terdapat kendala-kendala seperti jadwal-jadwal yang tidak berkesesuaian dengan jam mata kuliah mahasiswa, perbedaan pengelolaan oleh para dosen, perbedaan evaluasi antar dosen, bahkan ada yang tidak melakukan evaluasi, hingga faktor mahasiswa yang kurang berminat dalam mengikuti program wajib ini dan belum tersolusikan dengan baik. Ketiga, dari aspek outputnya. Karena program mengaji di Universitas Pamulang secara kurikulum belum dibakukan secara resmi, faktor pengajar dan pelajar memegang peranan penting dalam menentukan keberhasilan. Hal ini dapat dilihat dari peningkatan kemampuan dari kelas mahasiswa potensial terlihat cukup signifikan dari pada kelas tingkat dasar. Hal ini dipengaruhi oleh kemampuan awal peserta kelas mahasiswa potensial yang baik dalam membaca Al-Qur'an sehingga ketika belajar qiraah mujawwad tidak menemui kesulitan yang cukup berarti, dan juga pada kelas ini terdapat jam belajar tambahan seperti aktivitas rutin yang dilaksanakan di rumah pembimbingnya. Hal ini tidak terjadi pada kelas dasar. Jadi pada output program mengaji dapat disimpulkan bahwa terdapat dua macam peningkatan mengaji: pertama, peningkatan yang tidak signifikan pada level bimbingan mengaji dasar. Kedua, peningkatan mengaji yang cukup baik pada level bimbingan mengaji qira'ah mujawwad karena dipengaruhi dengan adanya jam tambahan yang dilaksanakan di rumah-rumah para pembimbing/ dosen.

\section{SIMPULAN}

Penelitian ini merupakan sebuah analisis tentang implementasi kurikulum program mengaji yang ada di kampus Universitas Pamulang kota Tangerang Selatan. Dari hasil temuan dan analisis menghasilkan kesimpulankesimpulan sebagai berikut:

a. Program mengaji Universitas Pamulang merupakan sebuah program pengembangan kurikulum mata kuliah Pendidikan Agama Islam dengan model grassroot bersifat wajib bagi mahasiswa semester awal yang bertujuan untuk memberantas buta huruf AlQur'an atau meningkatkan kemampuan membaca Al-Qur'an mahasiswa kepada tingkat yang lebih tinggi. Program ini mendapatkan dukungan oleh Rektor dan Ditjen Pendis Kementrian Agama.

b. Metode bimbingan membaca Al-Qur'an di Unpam yang menggunakan metode tahsin dasar I, tahsin dasar II, tahsin dasar III, tahsin dasar lanjutan, yang dilakukan selama satu semester. Metode bimbingan ini nampaknya belum bisa meningkatkan kemampuan mahasiswa secara signifikan terutama pada level dasar karena penggunaan metode yang belum fokus dan hanya menyentuh wilayah teori saja. Hal ini terlihat dari tidak adanya kurikulum dan sistem evaluasi yang baku. Masing-masing dosen berbeda dalam 
membimbing dan melakukan ujiaan tingkatan-tingkatan yang telah ditentukan. Sedangkan bagi mahasiswa potensial yang mempelajari qiraa'ah mujawwad, sebagian besar berhasil karena didukung oleh latar belakang pendidikannya ditambah adanya jam latihan intensif yang dilakukan di rumah dosen pembimbing.

c. Implementasi program mengaji Unpam memiliki kelebihan dan kekurangan. Mengacu kepada pendapat Andang tentang teori efektivitas ditinjau dari aspek input program mengaji ini sudah memiliki legalitas hukum, memiliki sasaran dan tujuan, dan memiliki sumber daya pengajar yang kompeten. Pada aspek proses, program ini berjalan kurang maksimal dan kurang efektif, terlihat dari segi pengelolaan jadwal yang seringkali bersamaan dengan jam mata kuliah lain, perbedaan standar pelaksanaan bimbingan antar dosen, perbedaan cara pandang tentang evaluasi, dan kurikulum belum dibakukan. Sedangkan pada aspek output, terdapat dua macam peningkatan mengaji: pertama, peningkatan yang tidak signifikan pada level bimbingan mengaji dasar. Kedua, peningkatan mengaji yang cukup signifikan pada level bimbingan mengaji qira'ah mujawwad dipengaruhi oleh latar belakang pendidikan mahasiswa dan jam tambahan di luar pembelajaran kampus.

\section{DAFTAR RUJUKAN}

Andang. (2014). Manajemen dan Kepemimpinan Kepala Sekolah Konsep, Strategi dan Inovasi Menuju Sekolah Efektif. Jakarta: Ar-Ruzz Media.

Arikunto, Suharsimi. (2002). Dasar-Dasar Evaluasi Pendidikan. Jakarta: Bumi Aksara.

Basyirudin, Usman. (2002). Metodologi Pembelajaran Agama Islam. Jakarta: Ciputat Press.
Idi, Abdullah. (2007). Pengembangan Kurikulum, Teori dan Praktik. Jogjakarta: Ar-Ruzz Media.

Kamus Besar Bahasa Indonesia daring, https://kbbi.web.id/religius, di akses tanggal 17 Februari 2021

Mangunwijaya. (1982). Sastra dan Religiositas. Jakarta: Sinar Harapan.

Muhaimin. (2010). Pengembangan Kurikulum Pendidikan Agama Islam di Sekolah, Madrasah, dan Perguruan Tinggi. Jakarta: Raja Grafindo Persada.

Nasution, S. (1999). Kurikulum dan Pengajaran. Jakarta: Bumi Aksara.

Regita Puji Agustin, Adi Suparwo, Wulan Yuliyana, Denok Sunarsi, \& Nurjaya. (2021). Pengaruh Kualitas Pelayanan terhadap Kepuasan Pelanggan serta dampaknya pada Word of Mouth Jasa Pengurusan Nenkin di CV Speed Nenkin. JIIP - Jurnal Ilmiah Ilmu Pendidikan, 4(3), 186-190. Retrieved from http://jiip.stkipyapisdompu.ac.id/jiip/index. $\mathrm{php} / \mathrm{IIIP} /$ article/view/249

Subarsono, AG. (2005). Analisis Kebijakan Publik: Konsep, Teori dan Aplikasi. Yogyakarta: Pustaka Pelajar.

Sukmadinata, Nana Syaodih. (2007). Pengembangan Kurikulum Teori Dan Praktek. Bandung: PT Remaja Rosdakarya.

Undang-Undang Republik Indonesia No. 20 tentang Sistem Pendidikan Nasional, Tahun 2003.

Undang-Undang Republik Indonesia Nomor 12 tentang Pendidikan Tinggi, Tahun 2012. 